\title{
Student's Creativity in Relation to Locus of Control: a Study of Mysore University, India
}

\author{
Prof. Anu Singh Lather*, Dr. Shilpa Jain**, Ms. Anju Dwivedi Shukla***,
}

\section{ABSTRACT:}

The study explored the relationship of creativity and locus of control of students coming from various academic disciplines (Biotechnology, Environmental Sciences, Civil Engineering, Electronics \& Communication, Centre for Women Studies, Mathematics, Food and Nutrition and Geography).The data was collected from a sample of 450 students of Mysore University out of which 40 belonged to Electronics and communication, 44 were from Civil Engineering, 40 from Environmental Sciences, 37 from Biotechnology, 40 from Geography, 16 from mathematics, 20 from Food and Nutrition and 7 from Centre for Women Studies. Abbreviated Torrance Test for Adults and Levenson's Locus of Control tests were administered on students and their socio demographic information was taken. Results showed that highly creative students are significantly higher on Internal Locus of Control and the students who were low on creativity are significantly higher on External Locus of Control. The study also found that students at post graduate level were significantly higher on Powerful Others as compared to students at under graduate level. Students with low creativity at both post graduate and undergraduate levels and from all disciplines are significantly higher on powerful others (external locus of control) as compared to the students with high creativity, while students with high creativity at post postgraduate and undergraduate level and from all disciplines are significantly higher on individual control as compared to students with low creativity at both the levels. The results also show that students from Geography are significantly higher on powerful others as compared to students from other disciplines, while students from centre for women studies are significantly lower on powerful others as compared to students from other academic disciplines except food and nutrition students. Students from Centre for women studies are significantly lower on chance control as compared to students from mathematics, environment sciences, biotechnology, civil engineering, and geography. However the students of geography are significantly higher on chance control as compared to students from mathematics, food and nutrition, electronics and communication, and centre for women studies.

Keywords: Creativity, Locus of Control, Education, Academic Disciplines

*Dean, **Assistant Professor, ***Research Scholar,

University School of Management Studies, Guru Gobind Singh Indraprastha University, Dwarka, New Delhi-110078

(c) 2014 A Singh Lather, S Jain, A Shukla; licensee IJIP. This is an Open Access Research distributed under the terms of the Creative Commons Attribution License (http://creativecommons.org/licenses/by/2.0), which permits unrestricted use, distribution, and reproduction in any Medium, provided the original work is properly cited. 


\section{Student's Creativity in Relation to Locus of Control: a Study of Mysore University, India}

\section{INTRODUCTION}

In the opening lines of Handbook of creativity Sternberg and Lubart (2004) said "If one wanted to select the best novelist, artist, entrepreneur or even chief executive officer, one would most likely want someone who is creative. Indeed, today many CEOs are selected not for their pleasant personalities or their learning and memory skills, but for their creative vision of how to turn a company around". Creativity is the ability to produce work that is both novel (i.e. original, unexpected) and appropriate (i.e. useful, adaptive concerning task constraints (Lubart, 1994). Man has been involved in the process of creative imagination since time immemorial. Toynbee (1964) has rightly remarked that, "a few creative minds can make enormous differences to civilization." Highly creative people are a national resource and such people should be identified at the school stage only and permitted to pursue the field of activity in which they show talent. It is essential that the nation should become concerned about all its potential human resources, especially aware of the waste and loss of such resources in each person (Taylor, 1978).

Torrance defined creativity as "the process of sensing problems or gaps in information, forming ideas of hypotheses, testing, and modifying these hypotheses, and communicating the results. This process may lead to any one of many kinds of products - verbal and nonverbal, concrete and abstract" (Torrance 1963). Many researchers have laboured to establish relationship between locus of control and creativity. Few recorded internal locus of control to be related with high creativity (Montea \& Siu, 2002; Ambile et al, 1990) while few found external locus of control to be associated with high creativity (Bolen \& Torrence, 1978; Richmond et al, 1980) and others found no relationship between the two (Brink, 2003).

The construct of LOC has been given considerable attention during the past two decades; it has been extensively researched in the areas of psychology (Phares, 1979; Basgall \& Snyder, 1988; Anderman \& Mindgly, 1997 and Carden, Bryant, \& Moss, 2004). Locus of control concept has been gaining importance in diverse disciplines in modern world starting from education, sports, organizations, religion etc. Some studies linking LOC with health have noted that internal health locus of control is linked with increased exercise, breast self-examination, weight control, non alcoholism, smoking cessation and preventative health behaviors but they also cite several studies that have found only a weak or no relationship. Maltby, Day and Macaskill (2007), which continue to cite studies linking internal locus of control with improved physical health, mental health and quality of life in people undergoing conditions as diverse as HIV, migraines, diabetes, kidney disease and epilepsy. Apart from this, locus of control has been cited to play an important role in religious orientation. Earlier Whyte correlated locus of control with academic success of students enrolled in higher education courses.

Locus of Control refers to an individual's generalized expectations concerning where control over subsequent events resides. Individuals with an Internal Locus of Control (ILOC) believe that the outcomes of events are internally controllable. In other words, they believe that their own personal efforts, behaviors or skills will influence and determine outcomes and they

take responsibility for their actions. On the contrary, individuals with an External Locus of Control (ELOC) believe that their behaviors or the events they experience are more determined 


\section{Student's Creativity in Relation to Locus of Control: a Study of Mysore University, India}

by external forces rather than by themselves. They believe and behave as if forces beyond their control such as chance, luck or others with greater power represent the important factors in determining the occurrence of reinforcing events (Rotter, 1966,1990). It has practical implications for business management practices because those individuals who have an internal locus of control are more likely to engage in more innovation than their counterparts who exhibit an external locus of control (Miller, Kets de Vries and Toulouse, 1982).

Rotter's conceptualization viewed locus of control as one-dimensional (internal to external) and Levenson's model asserts that there are three independent dimensions: Internality, Chance, and Powerful Others. Generally, the development of locus of control stems from family, culture, and past experiences leading to rewards. Most internals have been shown to come from families that focused on effort, education, and responsibility. On the other hand, most externals come from families of a low socioeconomic status where there is a lack of life control. An individual's belief about locus of control has been frequently studied as an antecedent to important social behaviors and psychological states. Specifically, the relationship between locus of control and gender (Manger and Eikeland, 2000) and between locus of control and such variables as achievement, teaching strategies and attribution (Sherris and Kahle, 1984; Park and Kim, 1998; Scharmann, 2006) have been investigated. Sherris and Kahle (1984) studied the effects of concept related teaching and locus of control on meaningful learning. The study concluded that teaching is not influential on meaningful learning, but those students with internal locus of control are more successful than those with external locus of control. Park and Kim (1998) made a comparison among students in terms of locus of control, attribution style and academic achievement. They concluded that those students with internal locus of control who are on the consistent honor list are much more successful than those with external locus of control. Those students with higher levels of achievement generally attribute their achievement to their own efforts and to the positive effects of other people, whereas, those students with lower levels of achievement attribute their underachievement to lack of skills or lack of support from other people.

Many studies and papers have been completed about how locus of control affects us in different areas of our lives (Lefcourt, 1976; Phares, 1976). However, there still lacks information in the area of whether locus of control is different for those persons with high education levels as compared to those persons with low education levels, also does locus of control differs for students belonging to different academic disciplines ? Looking at this paucity of literature we chose to compare locus of control of graduates and post graduates and locus of control of students of different academic disciplines.

\section{LITERATURE REVIEW}

Not many studies have been conducted to bring out the relation between locus of control with the education level of students. Erwin and Steinke (1973) in their study found that the generalized expectancy of reinforcement is related to level of academic program of Ontario grade 9 secondary school students. The student in the advanced level program is more internally controlled than either the general or basic level student. Cartledge (1985) conducted a study to 


\section{Student's Creativity in Relation to Locus of Control: a Study of Mysore University, India}

compare the locus of control of developmental studies, graduate, and undergraduate students enrolled in a four-year institution in the University System of Georgia. The findings clearly stated that graduate students had significantly more internal locus of control in comparison to undergraduates. Werner (1989) found that "resilient youths" had developed a positive selfconcept and internal locus of control by the time of their high school graduation. Johns (1992) in his study compared the locus of control of first- and second-grade students. He conducted his study on 591 students. The results showed that first-grade subjects had a significantly more external sense of control than second-grade subjects. Ponto (1999) conducted her study on three groups of 50 students in first, second and third of their diploma course and found no significant difference in Locus of Control between the groups. Schieman (2001) looking closely at the relationship between education and the sense of control determined that low education results in a loss of sense of control. Smith (2003) conducted a study on 100 male and female subjects of which 50 were non college-educated subjects with a high school education or less and 50 were graduate-level educated subjects with a graduate level education or higher and he found that graduate level and higher educated subjects possess a higher level of internal locus of control compared to those subjects of high school education or less. Slagsvold \& Sorenson (2008) in their study found that more education leads to increases in internal locus of control (Slagsvold \& Sorenson, 2008, p. 30). It is important in Turkish and Cypriot education system that students are internally controlled to enable them to be free willed, thinking and researching individuals who are able to bear the consequences of their actions. Therefore, it is important especially for teacher candidates to determine level of locus of control. Researches have shown that having an internal locus of control is related to higher academic achievement (Amadi, 2010).

When a review of existing literature was made in regard to Locus of Control of students of different academic disciplines, it was found that very few studies existed in this regard. Ponto (1999) conducted her study on first, second and third year students of nursing diploma course, to find the relation between LOC of nursing students and other student population. The results revealed that nursing students were more external in their LOC orientation than other student populations have been in the past. In their study Serin and Bulut Serin (2004) found that students of Guidance and Psychological Counseling are more internally controlled than students of Turkish Language Teaching and English Language Teaching. Ghonsooly \& Elahi (2010) found from their research that students of sciences have higher internal control orientation than students of Engineering, who also tend to have internal LOC. Engineering students, showed an External LOC. Zargham and Seyyed (2011), concluded from their research that students with an internal LOC are better achievers in the English section of the university entrance exam in comparison to students of humanities who have relatively higher external LOC. Haladyna \& Thomas (1977) found that students who have confidence in their own abilities, a sense of control of their own fate, and a feeling of being important, also have positive attitudes towards

science. This was also confirmed by the findings of Talton and Simpson (1985), who stated that students with a strong positive regard for their own abilities to learn have a more positive attitude toward science. 


\section{Student's Creativity in Relation to Locus of Control: a Study of Mysore University, India}

A lot of research has been conducted to establish the relation between LOC and creativity, but the number has been less in Indian context. Carl Rogers (1954) postulated that persons who possess openness to experience, an internal locus of control and an ability to toy with elements will, in a climate of psychological freedom, form a greater number of creative products. The Bialer (1961) locus of control scale and two creativity measures (Instances and Uses) adapted from Wallach and Kogan's (1965) creativity tasks were employed to test fluency, uniqueness and flexibility. The results do not present a clear pattern of findings. For all female subjects (particularly second graders) internality correlated with creativity as measured by the Instances creativity measure. For male kindergarten subjects, low internality correlated with creativity as measured by the Uses creativity measure. Lee (1971) conducted this study which involved 60 kindergarten and 69 second grade students sought to identify a significant relationship between internal control perception and creativity. Erwin and Steinke (1973) conducted a study on ninety 7 th, 8th, and 9th grade students, to study the relationship between scores on the Rotter's Internal-External scale, Guilford's Unusual Uses Test and a sorting task which examined their level of abstractness. No trends were seen between locus of control scores, measures of uncommonness and levels of abstractness. Glover and Sautter (1976) administered the Unusual Uses subtest of the Torrance Tests of Creative Thinking and the Rotter Social Reaction Inventory to 168 graduate students. Internals were found to have significantly higher scores on the flexibility and originality measures, while the externals had significantly higher elaboration scores. Richmond and De La Serna (1980) and Chadha (1989) found a significant relationship between creativity and internal locus of control. Bhogayata (1986) conducted a study to compare the creativity and locus of control of 1,014 students with 671 boys and 343 girls studying in Std. X of boys and girls. The findings revealed that the students with internal locus of control were more fluent, original and creative than the students with external locus of control. Chadha (1989) indicated that individuals with internal LOC were reported as being more creative overall. Fei Zi (1998) in his study on two hundred and fifty-five Chinese college students to find the relationship between locus of control and creativity among Chinese college students, it was discovered that the two dimensions of externality, especially chance perception, were more effective than internality in predicting creative abilities. Sayin (2000) stated that internal controlled individuals are creative. Park (2007) investigated the nature and extent of a potential link between creative attitudes and locus of control in fifth-grade children. Quantitative and qualitative methods were utilized in two phases. Results showed moderately high correlations between creative attitudes and internal locus of control as measured by two instruments on creativity (Group Inventory for Finding Talent, Creativity Attitude Survey) with both instruments on locus of control. Pannells et al. (2008) in their study explored the relationship between creative ideation and locus of control. Participants included 182 university students. Assessment tools included Runco Ideation Behaviour Scales, and Rotter's Locus of Control. Results indicated a relationship between creative ideation and external locus of control. 


\section{OBJECTIVES OF THE STUDY}

1. To compare the Locus of Control of students with different creativity levels.

2. To compare the Locus of Control (internal v/s external) of graduate and post graduate students with different creativity levels.

3. To compare the Locus of Control (internal v/s external) of students from various academic disciplines (Centre for Women studies, Mathematics, Food and Nutrition, Geography, Biotechnology, Environmental Sciences, Civil Engineering and Electronics \& Communication) with different creativity levels.

\section{RESEARCH METHODOLOGY}

\section{Research Design}

The sample has been selected on the basis of purposive sampling. The total sample selected consisted of 450 students studying in Undergraduate and Post Graduate level in University of Mysore. Out of 450, a total of 244 usable responses were obtained with return rate of $53.3 \%$. The research design is given below:

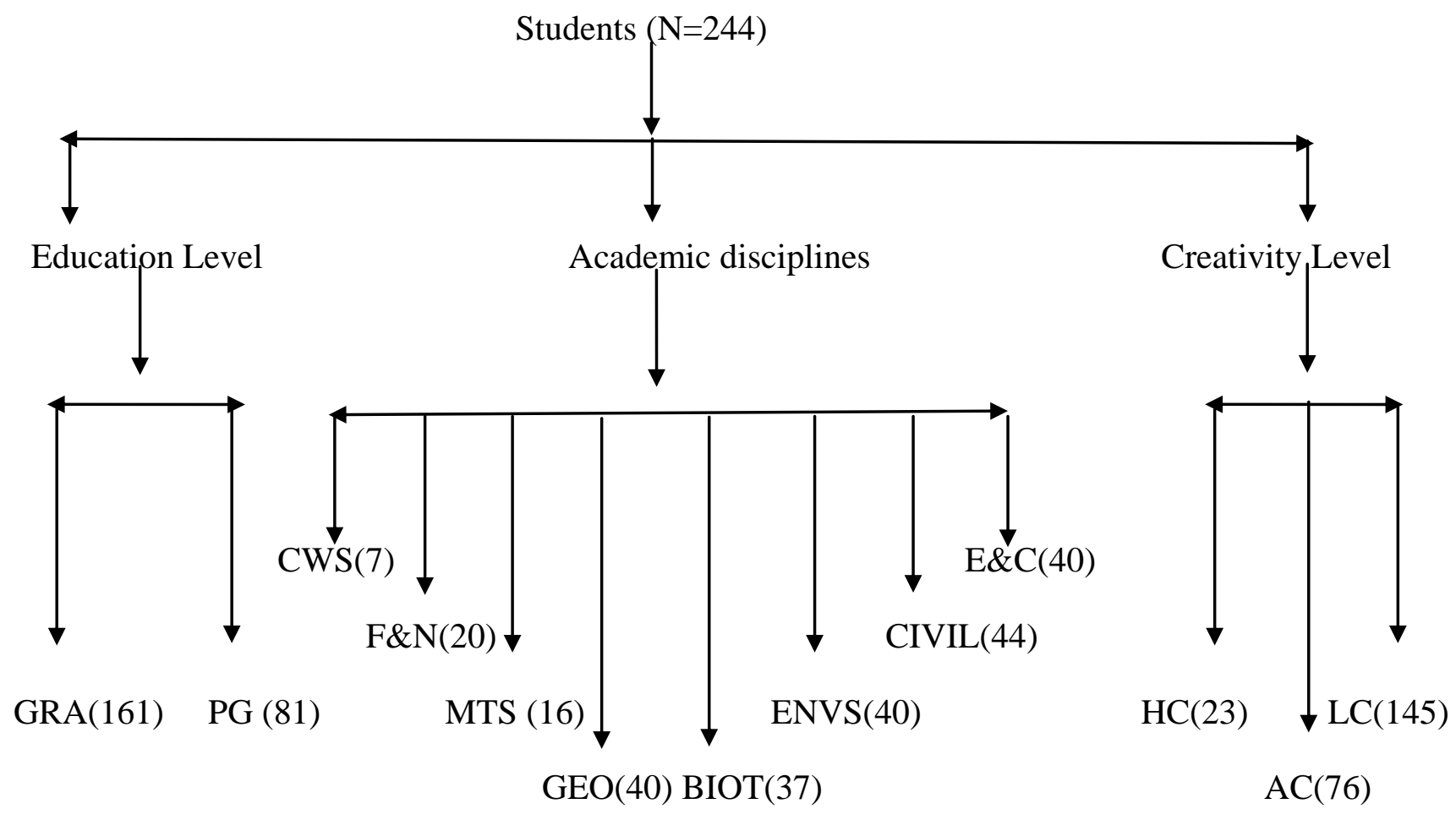

Here,

GRA $=$ Graduation

CWS $=$ Centre for Women Studies

$\mathrm{F} \& \mathrm{~N}=$ Food $\&$ Nutrition

GEO = Geography
$\mathrm{PG}=$ Post Graduation

$\mathrm{E} \& \mathrm{C}=$ Electronics $\&$ Communication

MTS= Mathematics

BIOT $=$ Biotechnology 
ENVS $=$ Environmental Science $\quad$ CIVIL $=$ Civil Engineering

$\mathrm{HC}=$ High Creative $\quad \mathrm{AC}=$ Average Creative

LC $=$ Low Creative

Survey Tools:

A three - part questionnaire was used for data collection.

\section{A) Socio- Demographic}

This part of the questionnaire was concerned with collecting socio-demographic details such as name, gender, age, educational level and academic disciplines.

\section{B) Abbreviated Torrance Test for Adults (ATTAs)}

The Torrance Tests of Creative Thinking (TTCT) "is the most widely used and most researched creativity test" (Goff \& Torrance, 2002, p. 36). The ATTA was developed from the TTCT and both content and face validity have been established by the Scholastic Testing Service (Goff \& Torrance).

The ATTA assessment consists of "four norm-referenced abilities and fifteen criterion referenced creativity indicators" (Goff \& Torrance, 2002, p. 1).

The four norm-referenced measures are identified as the following :

- $\quad$ Fluency- the ability to produce quantities of ideas which are relevant to the task instruction.

- Originality - the ability to produce uncommon ideas that are totally new or unique.

- $\quad$ Elaboration - the ability to embellish ideas with details.

- $\quad$ Flexibility - the ability to process information or objects in different ways, given the same stimulus.

The fifteen criterion-referenced creativity indicators included the following (Goff \& Torrance, p. 2):

- Verbal responses- which included richness and colourfulness of imagery, emotions and feelings, future orientation and humour, conceptual incongruity and provocative questions; and

- Figural responses- which included openness and resistance to premature closure, unusual visualization and different perspectives, movement and/or sound, richness and/or colorfulness of imagery, abstractness of titles, context or the environment for object and articulateness in telling story, combination and synthesis of two or more figures, internal visual perspective, expressions of feelings and emotions, and fantasy.

Raw scores from the four norm-referenced measures were converted to normalize scaled score, and were added to fifteen criterion-referenced indicators which received a score ranging from 0 to 2 , to create the creativity index (CI).

A seven- point scaled score was developed to interpret the resulting creativity index and Table 1 provides this essential information. 


\section{C) Locus of Control (LOC)}

Levenson and Miller (1976) multidimensional scale of I-E control was used to measure LOC. It has 24 items related to two sub areas namely internal control and external control. External control has two sub scales i.e. powerful others and chance. The subjects are required to respond to each item on a 5-point scale. The score on the 8 item of each sub-area was used as a score. The higher the score, greater is the subject's degree of expectancy for the particular aspect of locus of control.

\section{Data Collection and Analysis}

After seeking permission from the instructors, the researcher visited the classes in order to administer the questionnaires. The students were made certain that the results remain confidential and their instructors would not see the results of the questionnaires. The questionnaires were administered in one session under standard conditions. The directions of the questionnaires were in English; however, the researcher explained them once more so that participants would have a clear understanding of what they were supposed to do. The data collected were put into Statistical Package for Social Sciences (SPSS) to be analyzed.

\section{RESULTS}

\section{Creativity Levels, Different Academic disciplines and Locus of Control}

Table 1.1 shows the results of Two Way MANOVA with different academic disciplines and creativity as independent variables and factors of locus of control as dependent variable. The two way MANOVA revealed that various creativity levels impacted significantly on the combined dependent locus of control variables with Wilks' Lambda $=.702$, F value $=14.167$ and significance value $=.000$. The further scrutiny of the ANOVA table (Table 1.2) according to each variable shows that powerful others, chance control and individual control are significantly different according to creativity level. Scrutiny of the mean table and post hoc tables (Table 1.3, Table 1.3a, Table 1.3b, Table 1.3c) show that students who are high on creativity are significantly high on Individual control as compared to low creative students. The students low on creativity are significantly higher on powerful others and chance control as compared to high creative students.

The two way MANOVA (Table 1.1) revealed that Different Academic disciplines impacted significantly on the combined dependent variables of locus of control with Wilks' Lambda $=.75, \mathrm{~F}$ value $=3.05$ and significance value $=.00$. Further scrutiny of the ANOVA table (Table 1.2) according to each variable shows that powerful others and chance control are significantly different according to Academic disciplines . Analysis of the mean table (Table 1.4) shows that students from Geography discipline are high on Powerful others whereas students from Centre for Women Studies are lowest on Powerful Others. Again students from Geography 


\section{Student's Creativity in Relation to Locus of Control: a Study of Mysore University, India}

discipline score highest on Chance Control and students from Centre for Women Students score the lowest . Post Hoc Tests were applied for further analysis and the Duncan table (Table 1.4a) showed that Geography students were significantly high on Powerful others in comparison to students of Environmental Sciences, Civil Engineering, Electronics and Communication, Biotechnology, Mathematics and Food and Nutrition whereas students of Centre for Women Studies students were found to be significantly low on powerful other. Duncan table (Table 1.4b) which showed the relationship of Chance control on Different Academic disciplines revealed that Geography students were significantly high on Chance control, Mathematics students were moderate on chance control and Centre for Women Studies students scored the lowest on Chance control. The result shows that geography students scored highest on Powerful other and Chance control (high on external locus of control), whereas Center for Women Studies students scored lowest on Powerful others and chance control (low on Internal locus of control).

The result makes it clear that Geography student's belief is strongest in the fact that events occur because of chance, luck or others with greater power or some external forces beyond their control. And this thinking or belief of Geography students is very obvious because of the fact that their subject in itself directs their thinking to the facts that a lot of events occur which are not under their control like earthquake, volcanic eruptions, floods, tsunami etc. and these events are such which happen in the natural course and nothing is in individual control. And viewing the others where Centre for Women studies students who scored the lowest on the scale of Powerful others and Chance control can be explained by the fact that the subject material of this academic discipline has made the orientation of the students like that, and they belief that external forces have lesser role to play in their life, the students are taught to be sensitive towards women issues, take steps to empower them, remove disparity from society in relation to women and these teachings develop an orientation in students that situations are in their own hands and they have to work and improve the situations by themselves.

The two way MANOVA (Table 1.1) revealed that interaction between creativity level and different academic disciplines impacted significantly on the combined dependent variable locus of control with Wilks' Lambda $=.70, \mathrm{~F}$ value $=2.23$ and significance value $=.00$. The further scrutiny of the ANOVA table (Table 1.2) according to each variable shows that powerful others, Chance control and Individual Control are significantly different when creativity and different academic disciplines interacts. Analysis of the mean table (Table 1.5) shows that low creative students of Geography are highest on Powerful others and low creative students of Centre for Women students are lowest on Powerful others .Average creative students of Geography scored highest on Powerful Others and average creative students of Centre for Women studies scored lowest on Powerful others . Further High creative students of Centre for Women Studies have scored highest on Powerful Others and high creative students of Environmental Sciences and Civil Engineering have scored lowest on Powerful others. The mean table shows that low creative students of Civil Engineering are highest on Chance Control and low creative students of Centre for Women students are lowest on Chance Control .Average creative students of Geography scored highest on Chance Control and average creative students of Mathematics scored lowest on Chance Control. Further High creative students of Food and 


\section{Student's Creativity in Relation to Locus of Control: a Study of Mysore University, India}

Nutrition have scored highest on Chance Control and high creative students of Environmental Sciences and Civil Engineering have scored lowest on Chance Control. The mean table shows that low creative students of Geography are highest on Individual Control and low creative students of Centre for Women students are lowest on Individual Control. Average creative students of Biotechnology scored highest on Individual Control and average creative students of Geography scored lowest on Individual Control. Further High creative students of Biotechnology and Electronics and Communication have scored highest on Individual Control and high creative students of Centre for Women Students have scored lowest on Powerful others.

The results reveal that students from all the academic disciplines except food and nutrition who are high on powerful others and chance control are low on creativity and vice versa. However the students high on powerful others and chance control from food and nutrition academic discipline are average on creativity. The results also show that students from all the academic disciplines except geography who are high on individual control are high on creativity and vice versa, however in geography students lowest on individual control are average on creativity.

More or less the pattern of the results goes in line with the established relationship of internals being high on creativity and externals being low on creativity. This is probably because to be creative and innovative one has to have belief in self and acceptability of own behavior.

\section{Creativity, Education and Locus of Control}

The two way MANOVA (Table 2.1) revealed that Education level of students impacted significantly on the combined dependent variable locus of control with Wilks' Lambda $=.92, \mathrm{~F}$ value $=3.20$ and significance value $=.00$. The further scrutiny of the ANOVA table (Table 2.2) according to each variable shows that powerful others is significantly different according to Education level. Analysis of the mean table (Table 2.4) shows that Post Graduate students are high on Powerful others whereas Graduate Students are low on Powerful Others. The results obtained in this study regarding education level and locus of control is supported by the earlier findings of Rice (1992) and Whaley (1994), but it stands in contrast to previous research results which states that as the students attain higher education, they tend to become more internal (Cartledge, 1985; Johns, 1992; Schieman, 2001; Slagsvold \& Sorenson, 2008). By this study we can say, it's not always that the higher the educational level of a student more is his internal locus of control but instead it would be more appropriate to emphasize the fact that locus of control may fluctuate depending on the phase of life an individual is undergoing along with his educational level. This can further be attributed to the fact that most of the students at graduation level do not feel the pressure of competition to secure higher scores may be because this is not their showcase to the professional world for seeking job. However at post graduation level most of the students feel this pressure of securing more and more so that they can get best of the job. On the other hand high score at post graduation level is dependent on their faculty members and therefore feel controlled by powerful others (probably their faculties).

The two way MANOVA (Table 2.1) revealed that interaction between creativity level and Education Level impacted significantly on the combined dependent variable locus of control 


\section{Student's Creativity in Relation to Locus of Control: a Study of Mysore University, India}

with Wilks' Lambda $=.85, \mathrm{~F}$ value $=6.57$ and significance value $=.00$. The further scrutiny of the ANOVA table (Table 2.2) according to each variable shows that powerful others and Chance control and Individual Control are significantly different when creativity and Different level of Education interact. Analysis of the mean table (Table 2.5) shows that low creative Post Graduate students are highest on Powerful others and High Creative Graduate students are lowest on Powerful others. Average creative Post Graduate students scored highest on Chance Control and average creative Graduate students scored lowest on Chance Control. Further High creative Graduate students scored highest on Individual Control and low creative Graduate students have scored lowest on Individual Control. From the result it becomes clear that education level has no significant effect on individual control and chance control, but the interaction between creativity level and education level have significant impact on locus of control, and it is found that low creative Post Graduate students are highest on powerful others (External Locus of control) and low creative graduate students have scored lowest on Individual control (Internal locus of control). Further, high creative graduate students are lowest on Powerful others (External Locus of Control) and highest on Individual control (Internal Locus of control). So, we can say that students with Internal locus of control have higher level of creativity in comparison to students with external locus of control who seems to have an lower level of creativity.

These results can again be attributed to the above mentioned probabilities of post graduate students being high on powerful others. Also amongst these students those who are high on creativity may be able to score better because being high on creativity increases the practical implementation power of the student, which is the focus of higher education. You can score high at post graduate level if you know how to practically implement concepts and knowledge.

To conclude the result, it clearly shows that students who have are internal orientation (high Individual Control) are high on Creativity levels and the students who have an external orientation (High Powerful others and Chance Control) are low on Creativity levels. This means that high creative students believe that outcomes in their life depends on their own actions and choices whereas students who are low on creativity believe that outcomes depend on chance, fate or powerful other people. A student high on Individual control will have faith in himself and his ideas, he will not always follow the usual path to solve a problem instead he will look for alternative paths, he will not be afraid to make mistakes since he is confident about himself. A person with Internal Locus of Control has faith and belief in him; hence he will experiment with new and unique things which will ultimately lead to creativity. On the other hand students who have an external locus of control are not confident enough to decide for themselves; hence they follow the usual path set by others which will not lead to creativity.

\section{CONCLUSION}

The results obtained during the study bring out three clear cut understanding. Firstly, the students having an Internal Locus of Control are high on Creativity and the students who have an External Locus of Control are low on Creativity. Meaning thereby that high creative students believe that outcomes in their life depends on their own actions and choices whereas students who are low on creativity believe that outcomes depend on chance, fate or powerful other people. Secondly, 


\section{Student's Creativity in Relation to Locus of Control: a Study of Mysore University, India}

students having higher education level are high on External Locus of control in comparison to students of lower education level who have an Internal Locus of Control. This could be so because most of the students at graduation level do not feel the pressure of competition to secure higher scores may be because this is not their showcase to the professional world for seeking job. However at post graduation level most of the students feel this pressure of securing more and more so that they can get best of the job and a comfortable and settled life. On the other hand scoring high on post graduation level is difficult so the students feel that their scores are at the whims of their faculty and therefore feel controlled by powerful others. Lastly, looking at the locus of control of various academic disciplines, the decreasing order of External Locus of Control of various academic disciplines is falling as Geography being on top followed by sciences and engineering, mathematics, food and nutrition and Centre for Women studies has lowest External Locus of Control. This result can be explained in the terms of their orientation which has developed because of the subject they study i.e. in Geography we study the dynamics of ecological environment which is a natural phenomenon whereas in Centre for Women Studies the main idea of the subject matter is to develop sensitivity and belief in self. These results of significant differences in locus of control according to level of education and different academic disciplines is opposite to the popular notion that locus of control is usually permanent trait of personality. The results of this study opens the challenge for researchers to apply time series research or panel research to measure the changes in locus of control in set of individuals over the different phases of life.

\section{REFERENCES}

1. Amabile, T.N, Goldfarb,P., \& Brackfield, S.C. (1990). Social influences on creativity: Evaluation, co-action and surveillance. Creativity Research Journal, 3, pp 6-21.

2. Amadi, M. (2010). Affective Determinants of ESL Success, Unpublished M.Ed Project, Academic discipline of Teacher Education, University of Ibadan.

3. Anderman, L. H., \& Midgley, C. (1997). Motivation and middle school students. In Judith L. Irvin. (Ed.). What current research says to the middle level practioner, 1-48. Columbus, OH: National Middle School Association.

4. Bailer, I. (1961). Conceptualization of success and failure in mental retarded and normal children. Journal of Personality, 29, 303-320.

5. Basgall, J. A., \& Snyder, C. R. (1988). Excuses in waiting: External locus of control and reactions to success-failure feedback. Journal of Personality and Social Psychology, 54, 656-662.

6. Bert O. Richmond \& Marcelo De La Serna (1980). Creativity and Locus of Control among Mexican College Students. Psychological Reports: Volume 46, Issue, pp. 979983.

7. Bolen, L.M. \& Torrance, E.P. (1978). The influence of creative thinking of locus of control, cooperation, and sex. Journal of Clinical Psychology, 34, 903-907. 
8. Bozkurt N., Serin O. ve Emran B. (2004). Ilkögretim birinci kademe ögretmenlerinin problem çözme becerileri, iletisim becerileri ve denetim odag1 düzeylerinin karsilastırmalı olarak incelenmesi. XII. Egitim Bilimleri Kongresi Bildirileri. Gazi Üniversitesi Egitim Bilimleri Bölümü. Cilt II.

9. Brink, N.H. (2003). Locus of control, creativity in late middle childhood. Manuscript retrived from http://dspace.nwu.ac.za/bitstream/handle/10394/324/brink_nh.pdf?sequence=1

10. Carden, R., Bryant, C., \& Moss, R. (2004). Locus of control, test anxiety, academic procrastination and achievement among college students. Psychological Reports, 95(2), 581-582. doi: 10.5332/03000-4333.23.22

11. Cartledge, C.M. (1985). Locus of Control: A Comparison of Developmental Studies, Undergraduate, and Graduate Students. Paper presented at the Annual Developmental Studies Conference (Jekyll Island, GA, April, 1985).

12. Ducette, J., \& Wolk, S. (1972). Locus of control and extreme behavior. Journal of Consulting and Clinical Psychology, 39, 253-258.

13. Findley, M.J. \& Cooper H.M., (1983). Locus of control and academic achievement: A literature review. Journal of Personality and Social Psychology, 44, No. 2, 419 - 427.

14. Ghapanchi, Z. \& Golparvar, S.E. (2011). Locus of Control, Religious Orientation, and L2 Achievement. California Linguistic Notes, Volume 36 No. 2.

15. Ghonsooly, B. \& Elahi, M. (2010). Validating locus of control questionnaire and examining its relation to general English achievement. Journal of Teaching Language Skills, 2(1), 117-143.

16. Haladyna, T. \& Thomas, G. (1977). The attitude of elementary school children toward school and subject matters. Paper presented to the Annual Meeting of the American Educational Research Association, New Your City.

17. Johns, J.L. (1992). A comparison of the locus-of-control of first-and second-grade students in whole language, basal reader, and eclectic instructional approach classrooms. Doctoral thesis, Northern Illinois University.

18. Lefcourt, H. M. (1976). Locus of Control: Current trends in theory and research. Hillsdale, N.J.: Eribaum.

19. Lotsof, Erwin J.; Steinke, JoAnn (1973). Internal-external control, divergent thinking and levels of abstractness. Psychological Reports, 32, pp. 1035-1041.

20. Manger T, Eikeland O (2000). On the relationship between locus of control, level of ability and gender. Scandinavian J. Psychol.41 (3): 225-229.

21. Miller, Danny, Manfred F.R. Kets de Vries and Jean-Marie Toulouse (1982), "Top Executive Locus of Control and its Relationship to Strategy-Making, Structure and Environment," Academy of Management Journal, 25, pp. 237-253

22. Moneta, G.B., \& Siu, C.M.Y. (2002). Trait intrinsic and extrinsic motivations, academic performance, and creativity in Hong Kong college students. Journal of College Students Development, 43, 664-683.

23. Nowicki, S. D. \& Duke, M. P. (1974a). A locus of control scale for non-college as well as college adults. Journal of Personality Assessment, 38(2), 136-137. 


\section{Student's Creativity in Relation to Locus of Control: a Study of Mysore University, India}

24. Pannells, T.C. \& Claxton, F.A. (2008). Happiness, creative ideation and locus of control. Creativity Research Journal, 20(1), 67-71.

25. Park YS, Kim U (1998). Locus of control, attributional style, and academic achievement: comparative analysis of Korean-Chinese, and Chinese students. Asian J. Social Psychol. l(2): 191-208.

26. Phares, E.J. (1976). Locus of control in personality. Morristown, N.J: General Learning Press.

27. Ponto, M.T. (1999). Relationship between students' locus of control and satisfaction. Available from http://www.ncbi.nlm.nih.gov/pubmed/10222880

28. Richmond, B.O., \& De La Serna. M (1980). Creativity and locus of control among Mexican college students. Psychological Reports, 46, 979-983.

29. Rogers, C. (1954) "Toward a Theory of Creativity." ETC A Review of General Semantics 11:

30. Rotter, J. B., \& Mulry, R. (1965). Internal versus external control of reinforcements and decision time. Journal of Personality and Social Psychology, 2, 500-604.

31. Rotter, J.B., 1966. Generalized expectancies for internal versus external control of reinforcement. Psychological Monographs, 80: 1-28 (Whole No. 609).

32. Rotter, J.B., 1990. Internal versus external control of reinforcement: A case history of a variable. American Psychologist, 45: 489-493.

33. Sayin, S. (2000). Lise ögrencilerinin mesleki ilgilerini yordayan bazi degiskenler. Yayimlanmamis Yüksek Lisans Tezi, Hacettepe Üniversitesi, Sosyal Bilimler Enstitüsü, Ankara.

34. Scharmann LC (2006). The influences of sequenced instructional strategy and locus of control on preservice elementary teachers' understanding of the nature of science. J. Res. in Sci. Teaching, 25(7): 589-604.

35. Schieman, S. (2001). Age, education, and the sense of control: a test of the cumulative advantage hypothesis. Research on Aging vol. 23 (2), 153-178.

36. Sherris JD, Kahle JB (1984). The effects of instructional organization and locus of control orientation on meaningful learning in high school biology students. J. Res. in Sci. Teaching, 21(1): 83-94.

37. Slagsvold, B. \& Sorensen, A. (2008). Age, education, and the gender gap in the sense of control. International Aging and Human Development, Vol. 67(1), 25-42.

38. Smith, V.L. (2003). Analysis of Locus of Control and Education Level Utilizing the Internal Control Index. MA Thesis. Marshall University

39. Sternberg, R.J. \& Lubart, T.I. (1999). Handbook of Creativity, Cambridge University Press, pp: 3.

40. Taltont, E. L. \& Simpson, R. D. (1985). Relationships between peer and individual attitudes toward science among adolescent students. Science Education, 69: 19-24. http://dx.doi.org/10.1002/sce.3730690103

41. Werner, E.E. 1989. "High-risk children in young adulthood: A longitudinal study from birth to 32 years". American Journal of Orthopsychiatry, 59, 72-81. 


\section{ANNEXURE}

Table 1. The Scaled Score for the Creativity Index, with Added Interpretive Information.

\begin{tabular}{|c|c|c|}
\hline \multicolumn{3}{|c|}{ Abbreviated Torrance Test for Adult Scoring } \\
\hline $\begin{array}{c}\text { Scaled } \\
\text { Score }\end{array}$ & Percentage of Adults & Meaning \\
\hline 7 & 4 & Substantial \\
\hline 6 & 12 & High \\
\hline 5 & 20 & Above Average \\
\hline 4 & 26 & Average \\
\hline 3 & 20 & Below Average \\
\hline 2 & 12 & Low \\
\hline 1 & 4 & Minimal \\
\hline
\end{tabular}

Source : Goff \& Torrance, 2002, p. 29.

Table 1.1 : Summary of Multivariate Tests for the Factors of Locus of Control According to Academic disciplines and Creativity levels of students.

\begin{tabular}{|c|c|c|c|c|c|c|}
\hline Effect & & Value & $\mathrm{F}$ & $\begin{array}{c}\text { Hypothesis } \\
\text { df }\end{array}$ & $\begin{array}{l}\text { Error } \\
\text { df }\end{array}$ & Sig. \\
\hline Intercept & $\begin{array}{l}\text { Wilks' } \\
\text { Lambda }\end{array}$ & .057 & $1.222 \mathrm{E} 3$ & 3 & 220 & .000 \\
\hline creativity_level & $\begin{array}{l}\text { Wilks' } \\
\text { Lambda }\end{array}$ & .702 & 14.167 & 6 & 440 & .000 \\
\hline Academic disciplines & $\begin{array}{l}\text { Wilks' } \\
\text { Lambda }\end{array}$ & .758 & 3.053 & 21 & 632 & .000 \\
\hline $\begin{array}{l}\text { creativity_level * Academic } \\
\text { Disciplines }\end{array}$ & $\begin{array}{l}\text { Wilks' } \\
\text { Lambda }\end{array}$ & .709 & 2.233 & 36 & 650 & .000 \\
\hline
\end{tabular}

Table 1.2: Summary of Analysis of Variance for All Factors of Locus of Control According to Academic disciplines at three creativity levels.

\begin{tabular}{|l|l|r|r|r|r|r|}
\hline \multirow{3}{*}{ Source } & Dependent Variable & $\begin{array}{c}\text { Type III Sum of } \\
\text { Squares }\end{array}$ & df & Mean Square & \multicolumn{1}{c|}{ F } & Sig. \\
\hline creativity_level & powerful_others & 55.858 & 2 & 27.929 & 18.130 & .000 \\
\cline { 2 - 7 } & chance_control & 18.216 & 2 & 9.108 & 5.631 & .004 \\
\cline { 2 - 7 } & indi_cont & 103.906 & 2 & 51.953 & 22.096 & .000 \\
\hline $\begin{array}{l}\text { Academic } \\
\text { Disciplines }\end{array}$ & powerful_others & 75.275 & 7 & 10.754 & 6.981 & .000 \\
\cline { 2 - 7 } & chance_control & 39.842 & 7 & 5.692 & 3.519 & .001 \\
\cline { 2 - 7 } & indi_cont & 22.627 & 7 & 3.232 & 1.375 & .217 \\
\hline $\begin{array}{l}\text { Acadivity_level } \\
\text { Disciplines }\end{array}$ & powerful_others & 38.233 & 12 & 3.186 & 2.068 & .020 \\
\cline { 2 - 7 } & chance_control & 52.371 & 12 & 4.364 & 2.698 & .002 \\
\cline { 2 - 7 } & indi_cont & 69.490 & 12 & 5.791 & 2.463 & .005 \\
\hline
\end{tabular}


Table 1.3: Mean Scores of Creativity for the Factors of Locus of Control

\begin{tabular}{|l|l|l|l|}
\hline Dependent Variables & $\begin{array}{l}\text { Low } \\
\text { Creativity }\end{array}$ & $\begin{array}{l}\text { Average } \\
\text { Creativity }\end{array}$ & $\begin{array}{l}\text { High } \\
\text { Creativity }\end{array}$ \\
\hline Powerful Others & 7.14 & 6.34 & 4.73 \\
\hline Chance Control & 6.27 & 5.71 & 4.94 \\
\hline Individual Control & 4.92 & 6.59 & 7.73 \\
\hline
\end{tabular}

Table 1.3a: Test of homogenous subset - powerful others

\begin{tabular}{|c|c|c|c|c|}
\hline \multirow[b]{2}{*}{ creativity_level } & \multirow[b]{2}{*}{$\mathrm{N}$} & \multicolumn{3}{|c|}{ Subset } \\
\hline & & 1 & 2 & 3 \\
\hline high creativity & 23 & 4.6957 & & \\
\hline average creativity & 76 & & 6.5132 & \\
\hline low creativity & 145 & & & 7.4414 \\
\hline Sig. & & 1.000 & 1.000 & 1.000 \\
\hline
\end{tabular}

Table 1.3b: Test of homogenous subset - chance control

\begin{tabular}{|l|r|c|c|c|}
\hline & & \multicolumn{3}{|c|}{ Subset } \\
\cline { 3 - 5 } creativity_level & $\mathrm{N}$ & 1 & 2 & 3 \\
\hline high creativity & 23 & 4.9565 & & \\
\hline average creativity & 76 & & 5.8684 & \\
\hline low creativity & 145 & & & 6.5103 \\
\hline Sig. & & 1.000 & 1.000 & 1.000 \\
\hline
\end{tabular}

Table 1.3 c: Test of homogenous subset - individual control

\begin{tabular}{|l|r|c|c|c|}
\hline & & \multicolumn{3}{|c|}{ Subset } \\
\cline { 3 - 5 } creativity_level & $\mathrm{N}$ & 1 & 2 & 3 \\
\hline low creativity & 145 & 5.0483 & & \\
\hline avearge creativity & 76 & & 6.5395 & \\
\hline high creativity & 23 & & & 7.6957 \\
\hline Sig. & & 1.000 & 1.000 & 1.000 \\
\hline
\end{tabular}


Table 1.4: Mean Scores of Different Academic disciplines for the Factors of Locus of Control

\begin{tabular}{|c|c|c|c|c|c|c|c|c|}
\hline Dependent Variable & CWS & MTS & F \& N & GEO & BIOTECH & ENVS. & CIVIL & E\& C \\
\hline Powerful Others & 5.667 & 6.346 & 6.233 & 8.167 & 5.941 & 6.060 & 5.875 & 5.996 \\
\hline Chance Control & 5.111 & 5.487 & 5.981 & 7.000 & 5.641 & 5.644 & 5.661 & 5.478 \\
\hline Individual Control & 6.111 & 5.551 & 6.274 & 5.188 & 6.890 & 6.681 & 6.494 & 6.566 \\
\hline
\end{tabular}

Table 1.4a: Test of homogenous subset - Powerful Others

\begin{tabular}{|l|r|c|c|c|}
\hline & & \multicolumn{3}{|c|}{ Subset } \\
\cline { 3 - 5 } Academic Disciplines & \multicolumn{1}{|c|}{$\mathrm{N}$} & 1 & 2 & 3 \\
\hline centre for women studies & 7 & 5.5714 & & \\
\hline food and nutrition & 20 & 6.1500 & 6.1500 & \\
\hline Mathematics & 16 & & 6.5625 & \\
\hline Biotechnology & 37 & & 6.5946 & \\
\hline electronics and comm. & 40 & & 6.6250 & \\
\hline civil engg & 44 & & 6.8636 & \\
\hline environmental sc & 40 & & 6.9000 & \\
\hline Geography & 40 & & & 8.2000 \\
\hline Sig. & & .132 & .088 & 1.000 \\
\hline
\end{tabular}

Table 1.4b: Test of homogenous subset - Chance Control

\begin{tabular}{|l|r|c|c|c|}
\hline \multirow{2}{*}{ Academic Disciplines } & \multirow{2}{*}{$\mathrm{N}$} & \multicolumn{3}{|c|}{ Subset } \\
\cline { 3 - 5 } & 7 & 5.1429 & 2 & 3 \\
\hline centre for women studies & 40 & 5.8250 & 5.8250 & \\
\hline electronics and comm. & 20 & 5.9000 & 5.9000 & \\
\hline food and nutrition & 16 & & 6.0000 & \\
\hline Mathematics & 40 & & 6.0750 & 6.0750 \\
\hline environmental sc & 37 & & 6.1351 & 6.1351 \\
\hline Biotechnology & 44 & & 6.2500 & 6.2500 \\
\hline civil engg & 40 & & & 6.9000 \\
\hline Geography & & .069 & .354 & .055 \\
\hline Sig. & & & & \\
\hline
\end{tabular}


Table 1.5: Mean Scores of Creativity X Academic disciplines for All Factors of Locus of Control

\begin{tabular}{|c|c|c|c|c|}
\hline Dependent Variable & Academic disciplines & $\begin{array}{l}\text { Low } \\
\text { creativity }\end{array}$ & $\begin{array}{l}\text { Average } \\
\text { creativity }\end{array}$ & $\begin{array}{l}\text { High } \\
\text { creativity }\end{array}$ \\
\hline \multirow[t]{8}{*}{ Powerful Others } & Center for Women Studies & 6.000 & 5.333 & 5.667 \\
\hline & Mathematics & 6.692 & 6.000 & $\mathrm{a}$ \\
\hline & Food and Nutrition & 6.500 & 7.200 & 5.000 \\
\hline & Geography & 8.333 & 8.000 & $\mathrm{a}$ \\
\hline & Biotechnology & 6.923 & 5.900 & 5.000 \\
\hline & Environmental Sciences & 7.565 & 6.615 & 4.000 \\
\hline & Civil Engineering & 7.778 & 5.846 & 4.000 \\
\hline & $\begin{array}{l}\text { Electronics and } \\
\text { Communications }\end{array}$ & 7.391 & 5.846 & 4.750 \\
\hline \multirow[t]{8}{*}{ Chance Control } & Center for Women Studies & 5.000 & 5.333 & 5.000 \\
\hline & Mathematics & 6.308 & 4.667 & $\mathrm{a}$ \\
\hline & Food and Nutrition & 6.000 & 6.800 & 5.143 \\
\hline & Geography & 6.500 & 7.500 & $\mathrm{a}$ \\
\hline & Biotechnology & 6.423 & 5.500 & 5.000 \\
\hline & Environmental Sciences & 6.565 & 5.615 & 4.750 \\
\hline & Civil Engineering & 6.926 & 5.308 & 4.750 \\
\hline & $\begin{array}{l}\text { Electronics and } \\
\text { Communications }\end{array}$ & 6.435 & 5.000 & 5.000 \\
\hline \multirow[t]{8}{*}{ Individual Control } & Center for Women Studies & 4.000 & 7.000 & 7.333 \\
\hline & Mathematics & 4.769 & 6.333 & $\mathrm{a}$ \\
\hline & Food and Nutrition & 5.250 & 6.000 & 7.571 \\
\hline & Geography & 5.500 & 4.875 & $\mathrm{a}$ \\
\hline & Biotechnology & 5.269 & 7.400 & 8.000 \\
\hline & Environmental Sciences & 5.217 & 7.077 & 7.750 \\
\hline & Civil Engineering & 4.963 & 6.769 & 7.750 \\
\hline & $\begin{array}{l}\text { Electronics and } \\
\text { Communications }\end{array}$ & 4.391 & 7.308 & 8.000 \\
\hline
\end{tabular}

a. This level combination of factors is not observed, thus the corresponding population marginal mean is not estimable. 
Table 2.1: Summary of Multivariate Tests for the Factors of Locus of Control According to the Education and creativity levels of students.

\begin{tabular}{|l|l|r|r|r|r|r|}
\hline Effect & Value & F & Hypothesis df & Error df & Sig. \\
\hline Intercept & Wilks' Lambda & .145 & 4.62 & 3.00 & 235 & .000 \\
\hline creativity_level & Wilks' Lambda & .588 & 23.79 & 6.00 & 470 & .000 \\
\hline Education & Wilks' Lambda & .923 & 3.20 & 6.00 & 470 & .004 \\
\hline creativity_level * Education & Wilks' Lambda & .851 & 6.57 & 6.00 & 470 & .000 \\
\hline
\end{tabular}

Table 2.2: Summary of Analysis of Variance for All Factors of Locus of control According to the Education level of students at three creativity levels.

\begin{tabular}{|l|l|r|r|r|r|r|}
\hline \multirow{3}{*}{ Source } & Dependent Variable & $\begin{array}{c}\text { Type III } \\
\text { Sum of Squares }\end{array}$ & df & Mean Square & \multicolumn{1}{c|}{ F } & Sig. \\
\hline creativity_level & powerful_others & 146.952 & 2 & 73.476 & 41.812 & .000 \\
\cline { 2 - 7 } & chance_control & 38.762 & 2 & 19.381 & 11.550 & .000 \\
\cline { 2 - 7 } & indi_cont & 153.348 & 2 & 76.674 & 32.548 & .000 \\
\hline \multirow{3}{*}{ Education } & powerful_others & 20.522 & 2 & 10.261 & 5.839 & .003 \\
\cline { 2 - 7 } & chance_control & 7.524 & 2 & 3.762 & 2.242 & .109 \\
\cline { 2 - 7 }$*$ Education & indi_cont & 10.326 & 2 & 5.163 & 2.192 & .114 \\
\cline { 2 - 7 } & powerful_others & 15.776 & 2 & 7.888 & 4.489 & .012 \\
\cline { 2 - 7 } & chance_control & 33.844 & 2 & 16.922 & 10.085 & .000 \\
\cline { 2 - 7 } & indi_cont & 40.139 & 2 & 20.070 & 8.520 & .000 \\
\hline
\end{tabular}

Table 2.3: Mean Scores of Creativity for the Factors of Locus of Control

\begin{tabular}{|l|l|l|l|}
\hline Dependent Variables & Low Creativity & Average Creativity & High Creativity \\
\hline Powerful Others & 7.45 & 6.69 & 5.22 \\
\hline Chance Control & 6.46 & 6.08 & 4.99 \\
\hline Individual Control & 5.09 & 6.30 & 7.49 \\
\hline
\end{tabular}

Table 2.4: Mean Scores of Education Levels for the Factors of Locus of Control

\begin{tabular}{|c|c|c|}
\hline Dependent Variable & Graduate & Post Graduate \\
\hline Powerful Others & $\mathbf{5 . 9 2}$ & $\mathbf{6 . 5 6}$ \\
\hline Chance Control & 5.59 & 6.08 \\
\hline Individual Control & 6.64 & 6.10 \\
\hline
\end{tabular}


Table 2.5: Mean Scores of Creativity*Education level for the Factors of Locus of Control

\begin{tabular}{|l|l|l|l|l|}
\hline $\begin{array}{l}\text { Dependent } \\
\text { Variable }\end{array}$ & $\begin{array}{l}\text { Education } \\
\text { Level }\end{array}$ & $\begin{array}{l}\text { Low } \\
\text { Creativity }\end{array}$ & $\begin{array}{l}\text { Average } \\
\text { Creativity }\end{array}$ & $\begin{array}{l}\text { High } \\
\text { Creativity }\end{array}$ \\
\hline Powerful Others & Graduate & 7.41 & 6.06 & 4.30 \\
\hline & Post Graduate & 7.50 & 7.33 & 4.87 \\
\hline Chance Control & Graduate & 6.59 & 5.34 & 4.84 \\
\hline & Post Graduate & 6.32 & 6.81 & 5.12 \\
\hline Individual Control & Graduate & 4.97 & 7.12 & 7.84 \\
\hline & Post Graduate & 5.21 & 5.48 & 7.62 \\
\hline
\end{tabular}

